Kamil ŁAWNICZAK

DOI : $10.14746 / \mathrm{pp} .2018 .23 .1 .3$

Uniwersytet Warszawski

\title{
Śledzenie procesu w badaniach politologicznych. Warianty i potencjał zastosowania ${ }^{1}$
}

\begin{abstract}
Streszczenie: Śledzenie procesu (process-tracing) jest metodą analizy pojedynczego przypadku, która może służyć wyjaśnianiu przyczyn różnego rodzaju zjawisk w świecie społecznym. Skupienie metody na formułowaniu i weryfikowaniu teorii przyczynowych przyciaga uwagę osób prowadzących badania jakościowe, które nie chcą ograniczać ich zakresu jedynie do eksploracji i opisu. Śledzenie procesu ma też wariant zorientowany na przypadek, w którym teorie wykorzystywane są w pragmatyczny sposób jako instrumenty heurystyczne, co pozwala w systematyczny, ale zaraz kreatywny sposób badać poszczególne wydarzenia czy procesy. Ten artykuł podejmuje próbę pokazania, czym jest, a czym nie jest śledzenie procesu, jakie są jego warianty i jak powinno się je stosować. Jednocześnie podejmuje problem ontologicznych i epistemologicznych ograniczeń metody, wskazując na możliwości jej użycia w dociekaniach skupionych na ideach i interpretatywistycznych.
\end{abstract}

Słowa kluczowe: badania jakościowe, mechanizm przyczynowy, metodologia, studium przypadku, śledzenie praktyki

$\mathbf{T}$ eorie rozwijane w naukach o polityce mają zazwyczaj zastosowanie jedynie do określonego historycznie i kulturowo kontekstu (George, Bennett, 2005, s. 130). W wielu przypadkach badaczki i badacze porzucają uogólniające ambicje i skupiają się na szczegółach interesującego ich wycinka rzeczywistości społecznej. Ich analizy służą jak najlepszemu opisaniu zachodzących w tym wycinku procesów, istniejących w nim relacji i ukrytych zależności. W ten sposób nauki społeczne mogą przybliżać zrozumienie pewnych szczególnych aspektów świata społecznego. Inni starają się jednak doszukiwać związków przyczynowych w badanych obszarach, usiłując wyjaśnić skąd biorą się różnice między poszczególnymi państwami, grupami czy sytuacjami decyzyjnymi.

Wśród metod, które znajdują zastosowanie zarówno w jednym, jak i drugim podejściu, wyróżnia się śledzenie procesu (process tracing). Ta metoda analizy wewnątrz pojedynczego przypadku służy wypracowywaniu i weryfikacji wyjaśnień przyczynowych o różnym stopniu ogólności. Zyskuje ona w ostatnich latach popularność, czego przejawem są kolejne poświęcone jej publikacje (np. Beach, Pedersen, 2013; Kittel, Kuehn, 2013; Bennett, Checkel, 2015b; Beach, 2017; w Europie ŚrodkowoWschodniej np. Ławniczak, 2013; Mazák, 2017; Wiktorska-Święcka, Klimowicz, Michalewska-Pawlak, Moroń, 2017, s. 113-119). Wraz z popularnością śledzeniu procesu zaczyna jednak grozić utrata konkretnego znaczenia, gdy nazywane są tym mianem różne przedsięwzięcia badawcze nieposiadające uznanych w literaturze cech śledzenia procesu (Bennett, Checkel, 2015a, s. 4; por. Smeets, Vennix, 2014; Smeets,

${ }^{1}$ Niniejszy artykuł powstał w ramach projektu badawczego Mechanizmy socjalizacji $w$ procesie podejmowania decyzji w Radzie Unii Europejskiej. Projekt został sfinansowany ze środków Narodowego Centrum Nauki przyznanych na podstawie decyzji numer DEC-2013/09/N/HS5/00065. 
2016; zob. dane w: Czaputowicz, Ławniczak, 2015, s. 16, 66; Czaputowicz, Ławniczak, Wojciuk, 2015, s. 120).

Celem tego artykułu jest przedstawienie istoty metody śledzenia procesu, zwłaszcza tego, co odróżnia ją od innych studiów pojedynczego przypadku, jak również jej potencjału dla badań służących rozwojowi teorii. Opierając się na analizie literatury oraz własnym doświadczeniu w stosowaniu metody (zob. Ławniczak, 2017), staram się udzielić odpowiedzi na następujące pytania: jakie są wyróżniające cechy metody? czym różnią się od siebie (pod względem założeń i uwarunkowań praktycznych) jej poszczególne warianty? czy można za jej pomocą prowadzić dociekania skupione na ideach? jak daleko można odejść od pozytywistycznej „standardowej nauki” (Manners, Whitman, 2016)?

Tekst podzielony jest na cztery części. Pierwsza omawia kluczowe cechy śledzenia procesu, na czele z mechanistycznym ujęciem przyczynowości. Druga część służy wyjaśnieniu różnic między wariantami metody, jak i pokazaniu ich cech wspólnych. Opisane zostaną w niej poszczególne etapy badań prowadzonych z wykorzystaniem śledzenia procesu. Dwie ostatnie części artykułu służą zarysowaniu możliwości, jakie daje połączenie process tracing z ujęciami idealistycznymi i interpretatywistycznymi.

\section{Istota śledzenia procesu}

Określenie process tracing wywodzi się z psychologii, ale już pod koniec lat 70. XX wieku zaczęto nazywać tak niektóre badania historyczne w naukach o polityce (Bennett, Checkel, 2015a, s. 5-9; George, Bennett, 2005, s. 142). Współcześnie śledzenie procesu nie jest już związane $\mathrm{z}$ analizą historyczną, w szczególności zaś nie oznacza chronologicznego opisu następujących po sobie wydarzeń (choć nadal bywa tak rozumiane, por. Ruback, 2010, s. 478). Metoda ta polega na analizowaniu materiału empirycznego dotyczącego jednego przypadku w celu określenia, czy występują w nim dowody wskazujące na zaistnienie poszczególnych części składowych śledzonego procesu. Niekiedy takim dowodem może być sekwencja wydarzeń, ale w innych sytuacjach ten typ materiału może nie być przydatny (Beach, Pedersen, 2013, s. 5). Według Bennetta i Checkela (2015a, s. 7) process tracing to ,analiza procesów, następstw wydarzeń i punktów zwrotnych w badanym przypadku w celu sformułowania lub testowania hipotez dotyczących mechanizmów przyczynowych, które mogłyby wyjaśnić ów przypadek".

Śledzenie procesu należy do grupy metod jakościowych, to znaczy posługuje się głównie (choć nie wyłącznie) danymi w formie tekstu. Służy prowadzeniu analiz wewnątrz pojedynczego przypadku. W literaturze określa się badania jakościowe jako badania „małych N" (small-N studies), w odróżnieniu od statystycznych badań „dużych N” (large- $N$ studies). „N” oznacza liczbę przypadków poddawanych analizie. „Przypadek” to pojedynczy przedmiot badania, należący do pewnej klasy zdarzeń bądź zjawisk², które są przedmiotem naukowego zainteresowania (George, Bennett, 2005, s. 17). Przy badaniu jakościowym wielkość $\mathrm{N}$ jest ograniczona ze względu na ich zamierzoną szcze-

${ }^{2}$ „Klasy zdarzeń bądź zjawisk” to konstrukcje społeczne - stanowione po części przez aktorów społecznych, a po części przez osoby, które wyodrębniają je na potrzeby prowadzonych badań, definiując kategorie, które pozostają zależne od podtrzymywanych przez nie konceptów, por. Bennett, Checkel, 2015a, s. 8. 
gółowość. Często przedmiotem badania jest tylko jeden przypadek. Badacze i badaczki posługujący się metodami ilościowymi tworzą natomiast bazy zawierające dane dotyczące wielu przypadków.

Oba podejścia, używane stosownie do specyfiki obiektów zainteresowań, mają swoje miejsce w naukach społecznych (Wendt, 2008, s. 84; por. Szymański, 2015). W przypadku śledzenia procesu kluczowa jest możliwość dociekania jak, za pośrednictwem mechanizmów przyczynowych, kształtowane są zjawiska w świecie społecznym (Schimmelfennig, 2015, s. 100). Śledzenie procesu pomaga rozwijać teorie, w tym warunkowo je uogólnia, z uwzględnieniem wywiedzionych z danych wniosków dotyczących np. warunków występowania związku przyczynowego (Bennett, Checkel, 2015a, s. 13).

Znaczenie ma specyfika przedmiotu badań nauk społecznych. Społeczne procesy, podmioty, zjawiska i wydarzenia mają charakter historyczny, zależny od podtrzymywanych przez ludzi przekonań, wierzeń, etc., oraz ich praktyk i relacji (por. Wendt, 2008, s. 72-74). Osoba prowadząca dociekania może jedynie w ograniczonym zakresie wyodrębnić to, co bada, z tych przygodnych kontekstów. Dlatego teorie w naukach społecznych muszą uwzględniać ograniczenia określające zasięg ich obowiązywania (zob. niżej; por. Wendt, 2008, s. 77-78).

Istotą process tracing jest śledzenie mechanizmów przyczynowych, co odróżnia je od innych rodzajów studium przypadku, jak np. analityczna narracja (Beach, 2013, s. 13-14; Beach, Pedersen, 2013, s. 13-14; por. Bates et al., 1998). Wiąże to metodę $\mathrm{z}$ teoriami przyczynowymi, które z jej pomocą można rozwijać lub weryfikować. Teorie te odpowiadają na pytania o to, „dlaczego” oraz w pewnym stopniu również „w jaki sposób" zachodzą pewne społeczne zjawiska. Określa się w nich przyczynę (X) i skutek (Y), które spełniają trzy warunki: X i Y istnieją niezależnie, $\mathrm{X}$ poprzedza $\mathrm{Y}$, a gdyby nie $\mathrm{X}$, to nie wystapiłoby $\mathrm{Y}^{3}$ (Wendt, 2008, s. 80-81).

Metody ilościowe służą poszukiwaniu korelacji między różnymi $\mathrm{X}$ a danym $\mathrm{Y}$, które niekiedy pozwalają wnioskować na temat związków przyczynowo-skutkowych. Nie mają wiele do powiedzenia o tym, w jaki sposób przyczyny wywołują skutki oraz jakie mechanizmy pośredniczą w procesie przyczynowym. Badania „małych N” nie mogą stwierdzać korelacji, ale jednocześnie wolne są od upraszczających założeń, koniecznych w badaniach „,dużych N”. Często oznacza to budowanie szczegółowych narracji, w których wyszczególnia się serię następujących po sobie zdarzeń, prowadzących od hipotetycznej przyczyny do zaobserwowanego skutku (Checkel, 2005, s. 14-15; Beach, Pedersen, 2013, s. 33-34; Bennett, Checkel, 2015a, s. 9).

Badaczki i badacze posługujący się śledzeniem procesu skupiają się nie na przyczynach i skutkach, ale na tym, w jaki sposób są one powiązane. Podczas gdy metody ilościowe szukają probabilistycznej regularności współwystępowania przyczyn i skutków, process tracing służy poszukiwaniu pojedynczych wystapień ujmowanych deterministycznie mechanizmów (Beach, Pedersen, 2013, s. 25-28; Bennett, Checkel, 2015a, s. 12; por. Burnham et al., 2008, s. 174-176; Rohlfing, 2013).

Ujęcie przyczynowości w kategoriach mechanizmów bywa kojarzone z podejściami racjonalistycznymi, ontologicznie indywidualistycznymi, a epistemologicznie bliskimi

${ }^{3}$ Teorie dotyczące świata społecznego rzadko spełniają ściśle trzeci warunek, bo różnorodne społeczne skutki mają często wiele przyczyn, z których w jednym przypadku działa jedna, w innym druga, etc. 
pozytywizmowi. $\mathrm{W}$ istocie jednak śledzeniu procesu bliższe są umiarkowane stanowiska w obu kwestiach (Wendt, 2008, s. 11-12; Bennett, Checkel, 2015a, s. 21; por. Trondal, 2001, s. 4). Bennett i Checkel (2015a, s. 10) za najbardziej odpowiedni epistemologiczny fundament dla śledzenia mechanizmów przyczynowych uznają realizm naukowy. Stanowisko to głosi, że świat istnieje niezależnie od umysłów poszczególnych obserwatorów, a dojrzałe teorie naukowe odnoszą się do tego świata, nawet jeśli nie poddaje się on bezpośredniej obserwacji (Wendt, 2008, s. 56). Teorie są „prawdziwe” o tyle, o ile lepiej niż konkurencyjne oddają przyczynową strukturę świata (Wendt, 2008, s. 65).

Mechanizmy przyczynowe można porównać do kół zębatych, które przekazują „,siły” stojące za związkiem przyczynowo-skutkowym (por. Beach, Pedersen, 2013, s. 29). Przy ich konceptualizacji określa się pewne podmioty oraz aktywności, których te pierwsze się podejmują, co ma oddać dynamikę analizowanego procesu. Ujęcie związków przyczynowo-skutkowych w formie mechanizmów sprzyja klarowności i pokazuje drogę „sił przyczynowych” między przyczyną a skutkiem (Checkel, 2007, s. 9; Mayntz, 2004, s. 239; Burnham et al., 2008, s. 175, 178). Stanowi to wyróżnik process tracing - Derek Beach i Rasmus Brun Pedersen twierdza, że jest to w ramach nauk politycznych ,jedyna metoda, która pozwala badać mechanizmy przyczynowe" (Beach, Pedersen, 2013, s. 1-2).

Istnieją różne definicje mechanizmów przyczynowych. Według George’a i Bennetta (2005, s. 137) są to „fizyczne, społeczne lub psychologiczne procesy”, poprzez które, w określonych warunkach, jedne podmioty przekazują innym energię, informację lub materię, w wyniku czego pewne ich cechy, możliwości lub skłonności zmieniają się we względnie trwały sposób - dopóki nie zostaną one poddane działaniu kolejnych mechanizmów. Beach i Pedersen (2013, s. 29) definiują mechanizm przyczynowy jako, ,proces w konkretnym systemie, który może spowodować pewną zmianę w systemie jako całości lub którymś z jego podsystemów, albo zapobiec takiej zmianie". Według Bennetta i Checkela (2015a, s. 12) mechanizmy przyczynowe to byty istniejące w świecie, a zarazem teorie i hipotezy w umysłach osób prowadzących badania. Nie można ich zaobserwować bezpośrednio, jednak z hipotez ich dotyczących można wywieść poddające się obserwacji i weryfikacji implikacje (inne ujęcia - por. Mayntz, 2004, s. 239-241; Tilly, 2001, s. 25-26).

Uchwycenie działania mechanizmów przyczynowych stanowi istotę śledzenia procesu (Bennett, Checkel, 2015a, s. 9; Ławniczak, 2017, s. 81-86). Aby analiza była przekonująca, konieczne jest klarowne określenie tego, co dany mechanizm obejmuje, a czego nie. Oznacza to zarówno ustalenie warunków występowania mechanizmu, jak i jego przejawów. Dążenie do udoskonalania konceptualizacji i operacjonalizacji mechanizmów przyczynowych pozwala pełnić im funkcję ,narzędzi heurystycznych”, które pomagają wyjaśnić przebieg procesów przyczynowych (Beach, Pedersen, 2013, s. 45-48, 107, 119).

\section{Warianty metody}

Śledzenie procesu można wykorzystać do różnych celów. Beach i Pedersen (2013, s. 3) wyróżniają trzy główne warianty metody, służące:

a) weryfikowaniu teorii (theory-testing); 
b) formułowaniu teorii (theory-building);

c) wyjaśnianiu rezultatów (explaining-outcome).

Pierwszy z nich ma charakter dedukcyjny, a dwa pozostałe - indukcyjny. Teoretyczne, uogólniające ambicje dwóch pierwszych przeciwstawić można natomiast skupieniu na przypadku ostatniego wariantu. Teorie traktowane są w nim pragmatycznie, jako heurystyczne narzędzia używane w celu znalezienia najlepszych możliwych wyjaśnień, najpełniejszego zrozumienia interesujących przypadków (Beach, Pedersen, 2013, s. 9-13).

\section{Weryfikowanie teorii}

Śledzenie procesu służące weryfikowaniu teorii polega na ustalaniu, czy mechanizmy wywiedzione z jakiejś teorii (por. Kuehn, 2013) występują w analizowanym przypadku, należącym do jakiejś szerszej klasy przypadków. Mechanizmy te są operacjonalizowane, to znaczy oczekiwania wynikające z teorii są przekładane na przewidywania (specyficzne dla przypadku i uwzględniające kontekst) dotyczące możliwych do zaobserwowania przejawów działania tych mechanizmów. Przejawów tych poszukuje się następnie w materiale empirycznym. Metoda nie daje odpowiedzi na to, czy dany mechanizm jest konieczny dla zaistnienia określonego skutku ani tego, czy inne mechanizmy nie wyjaśniają rzeczywistości „lepiej”, a jedynie, że poszukiwany mechanizm występuje albo nie występuje (Beach, Pedersen, 2013, s. 14-16).

Dla powodzenia analizy kluczowe znaczenie ma zarówno odpowiednia konceptualizacja mechanizmów przyczynowych, jak i wybór przypadku, który będzie analizowany. $\mathrm{W}$ pierwszej kwestii istotne jest właściwe uwzględnienie aktorów uczestniczących w badanym procesie i tego jak ich działania prowadzą do oczekiwanego rezultatu (Schimmelfennig, 2015, s. 105-106). Należy mieć na uwadze możliwość operacjonalizacji mechanizmu, czyli formułowania przewidywań dotyczących dowodów, których oczekujemy, jeżeli mechanizm ów zaistniał w danym przypadku (Beach, Pedersen, 2013, s. $100-101)$.

Wybór przypadku powinien natomiast uwzględnić cel, jakim jest weryfikowanie teorii. Właściwe może być tu wybranie tzw. przypadku najmniej prawdopodobnego (least likely case). Dowody występowania śledzonego mechanizmu przyczynowego będą wówczas silniejszym argumentem na rzecz wartości testowanej teorii (Schimmelfennig, 2015, s. 105-106). Jednakże, jeżeli brakuje przekonania o samym występowaniu związku przyczynowego, bardziej odpowiedni będzie tzw. przypadek najbardziej prawdopodobny (most likely case; Beach, Pedersen, 2013, s. 151-152).

Surowe dane nie ujawniają osobie prowadzącej badania, czy poszukiwane przez nią mechanizmy przyczynowe wystapiły w danym przypadku. Obserwacje muszą zostać poddane krytycznej ocenie - jedynie uzupełnione o wiedzę analizującej je osoby stają się materiałem dowodowym i mogą służyć wyciaganiu wniosków (Beach, Pedersen, 2013, s. 73). Według Beacha i Pedersena (2013, s. 99-100) można wyróżnić cztery typy dowodów: wzorzec (pattern), dotyczący statystycznej regularności; sekwencja (sequence), czyli następstwo czasowe i przestrzenne; ślad (trace), to znaczy istnienie dowodu samo w sobie; relacja (account), czyli treść materiału empirycznego, takiego jak rozmowa, protokół z obrad, etc. 
Przyczynowości jako takiej nie da się zaobserwować, zatem konieczne jest wnioskowanie na jej temat $\mathrm{z}$ tego, co można zaobserwować. W przypadku omawianego tu wariantu śledzenia procesu istotne znaczenie ma ocena znaczenia dowodów wywiedzionych z materiału empirycznego (Burnham et al., 2008, s. 171, 185; por. Kittel, Kuehn, 2013, s. 2). Beach i Pedersen sugerują podejście bayesowskie (Ławniczak, 2017, s. 89-90), w którym pojedyncze dowody zmieniają przekonanie o prawdziwości danej teorii zależnie od tego, na ile są dla niej unikalne, a ich występowanie pewne (Beach, Pedersen, 2013, s. 25, 28, 83-87).

Kluczowe znaczenie mają testy, którym poddajemy hipotezy. Im są one silniejsze, to znaczy pewniejsze i bardziej unikalne, tym większą zmianę przekonania o występowaniu lub niewystępowaniu danego mechanizmu przyczynowego uzyskujemy. W uproszczeniu: im bardziej nietypowego, zaskakującego dowodu poszukujemy, tym lepiej większą wartość przynosi nam jego znalezienie (i przeciwnie - im dowód bardziej oczywisty, tym większe znaczenie będzie miał jego brak w materiale; Beach, Pedersen, 2013, s. 96-97)

Testy empiryczne w śledzeniu procesu służą uchwyceniu empirycznych przejawów działania teoretycznie skonceptualizowanych mechanizmów przyczynowych. Biorąc pod uwagę unikalność i pewność testów, można wyróżnić ich cztery rodzaje (Beach, Pedersen, 2013, s. 101-102; por. Evera, 1997; zob. tabela 1). Zdaniem Beacha i Pedersen (2013, s. 104-105) spośród czterech rodzajów testów najbardziej użyteczne są testy konieczne niewystarczające (hoop tests), pozwalające osłabiać przekonanie o występowaniu mechanizmu, gdy brakuje dowodów na jego występowanie.

Tabela 1

Rodzaje testów empirycznych w śledzeniu procesu

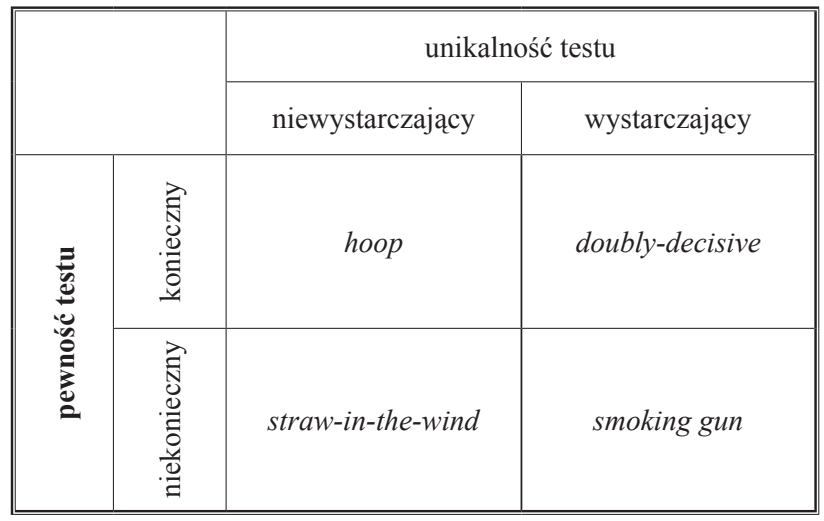

Źródło: Beach, Pedersen, 2013, s. 103.

Znaczenie bayesianizmu dla indukcyjnych wariantów śledzenia procesu jest ograniczone (Bennett, Checkel, 2015a, s. 16-17). Kluczowe pozostaje przekonanie, że dowody są istotne wówczas, gdy zwiększają lub zmniejszają przekonanie o zaistnieniu pewnego faktu, istotnego dla dociekań.

\footnotetext{
${ }^{4}$ Zob. przedstawienie tego rozumowania w formie liczbowej: Beach, Pedersen, 2013, s. 84-85.
} 


\section{Formulowanie teorii i wyjaśnianie rezultatów}

Indukcyjne warianty śledzenia procesu więcej łączy niż dzieli (por. Beach, Pedersen, 2013, s. 157). Punktem wyjścia są tu dane, a efektem analizy jest konceptualizacja mechanizmów przyczynowych wyjaśniających, w możliwie kompletny i spójny sposób (Waldner, 2015, s. 128), pewną klasę przypadków (formułowanie teorii) albo tylko jeden, szczególny przypadek (wyjaśnianie rezultatów). Uprzednio wypracowane teorie mogą jednak być przydatne, np. ukierunkowując poszukiwania materiału dowodowego (por. Ławniczak, 2015, s. 127).

Pod względem procedury, formułowanie teorii z pomocą śledzenia procesu jest odwrotnością ich testowania. Analiza zebranych danych służy interpretacji zawartych w nich dowodów i wychwyceniu tego, co może być przejawem działania mechanizmów przyczynowych. Podejmuje się tu „odwróconą operacjonalizację", konceptualizując zgodne $\mathrm{z}$ tak przetworzonym materiałem empirycznym mechanizmy przyczynowe, składające się na wyjaśnienie jakiegoś fenomenu obowiązujące dla określonej klasy przypadków. Jest to zazwyczaj proces wieloetapowy i wymagający kreatywności. Śledzenie procesu, służące formułowaniu teorii, zawiera konieczne przy interpretacji danych elementy dedukcyjne - dowody nie mówią bowiem same za siebie. Teorie są tu jednak raczej narzędziami czy podpowiedziami niż kompletnymi rozwiązaniami do przyjęcia (Beach, Pedersen, 2013, s. 16-18). Wariant ten można stosować zarówno wtedy, gdy związek przyczynowy jest ustalony, a teoria ma wyjaśnić przebieg procesu przyczynowego, jak i gdy poszukiwane są inne dotychczas zidentyfikowane przyczyny zaistnienia określonego skutku (Beach, Pedersen, 2013, s. 154-156).

Strategia badawcza śledzenia procesu służącego wyjaśnianiu rezultatów ma charakter iteracyjny. Podobnie jak poprzednio, zaczyna się od zebranych danych, jednak jej celem jest wyjaśnienie określonego przypadku, a nie formułowanie teorii dla klasy przypadków. W tym wariancie dokonuje się oceny znaczenia danych według różnych teorii, zmierzając do sformułowania wyjaśnienia, które będzie można uznać na wystarczające, czyli odnoszące się do istotnych cech rezultatu w badanym przypadku (Beach, Pedersen, 2013, s. 18-21; Ławniczak, 2013, s. 77; Zürn, Checkel, 2007, s. 242). W tym „wnioskowaniu do najlepszego wyjaśnienia" dostrzec można wpływ realizmu naukowego (Beach, Pedersen, 2013, s. 13, 19-21; Wendt, 2008, s. 67, por. Evangelista, 2015).

\section{Mechanizmy przyczynowe a teorie ideowe}

Jeżeli zgodzimy się z Markiem Blythem (2002, s. 17), że błędem jest pomijanie znaczenia idei dla kształtowania życia politycznego (por. Schmidt, Thatcher, 2013; Ławniczak, 2014), można zastanawiać się, na ile śledzenie procesu może być przydatną metodą badań skupionych na czynnikach ideowych. W tego typu dociekaniach próbuje się zgłębiać struktury ideowe, czy też rozkłady społecznej wiedzy (przekonań uznawanych za prawdziwe) i ich wpływ na procesy polityczne, np. idei i przekonań negocjatorów w kontekście międzynarodowym (Wagner, 2008, s. 8; Wendt, 2008, s. 135; por. Berger, Luckmann, 2010). Jak wskazują Finnemore i Sikkink (1998, s. 890), osoby prowadzące badania naukowe powinny jasno definiować ideowe twierdzenia i mechanizmy przyczy- 
nowe, biorąc pod uwagę mikrofundamenty, na których opierają swoje teoretyczne propozycje oraz oceniać je w ramach starannie zaprojektowanych badań. Metoda process tracing, jak pokazano wyżej, wydaje się wpisywać w te oczekiwania. Alan M. Jacobs (2015, s. 41) argumentuje, że śledzenie procesu jest szczególnie przydatne dla rozróżniania efektów czynników materialnych i ideowych.

Przyczynowe wyjaśnienia (lub teorie) ideowe to takie, w których o tym, jak ludzie postępują w pewnej sytuacji decyduje zawartość ich struktur poznawczych, a te nie są jedynie odzwierciedleniem pewnych obiektywnych, materialnych cech tej sytuacji (nie są względem niej endogenne). Struktury te mogą zawierać zobowiązania normatywne, przekonania o świecie, modele i analogie, etc. będące źródłem specyficznych zapatrywań danej jednostki. W tym ujęciu wyjaśnienia ideowe przeciwstawiane są materialistycznym, a różnica między nimi tkwi w tym, gdzie znajdują się źródła zróżnicowania wyborów dokonywanych przez podmioty sprawcze: w zmianach warunków materialnych czy też w zmianach zawartości umysłów jednostek. W teoriach ideowych idee są egzogenne dla danej sytuacji wyboru, choć mają zapewne jakiś związek z czynnikami materialnymi spoza danej sytuacji (Jacobs, 2015, s. 43-44).

Weryfikowanie wyjaśnienia ideowego niesie za sobą szereg wyzwań. Trudno jest zaobserwować, co dzieje się w umysłach ludzi. Jedyne czym dysponujemy, to relacje uczestników danej sytuacji na jej temat, które jednak nierzadko obarczone są błędem, zwykle na korzyść wyjaśnień ideowych. Wyzwaniem jest również uchwycenie mechanizmów, które w dużej mierze pozostają intrapersonalne (wewnętrzne), a także wyodrębnienie aspektów materialnych i ideowych - w praktyce okoliczności i uwarunkowania materialne i ideowe często idą w parze, popychając aktorów w tę samą stronę (Jacobs, 2015, s. 45-47).

Uwarunkowania te wymagają szerszego ujęcia przy zastosowaniu śledzenia procesu. Może nie wystarczyć ograniczenie się jedynie do kilku punktów krytycznych w analizowanym procesie, bo mogłyby one nie uchwycić wszystkich elementów istotnych dla uwiarygodnienia (lub odrzucenia) wyjaśnienia ideowego (por. Ławniczak, 2015, s. 130). Osoba prowadząca badania musi poszukać śladów ideowych mechanizmów przyczynowych na poziomie interpersonalnym, na przykład poprzez analizę komunikacji. W dociekaniach trzeba brać pod uwagę to, że aktorzy polityczni mogą z różnych powodów nie chcieć ujawniać swoich prawdziwych motywacji. Z drugiej strony, konieczne jest zwracanie uwagi również na to, co nie jest powiedziane, co stanowi dla aktorów oczywistą, powszechną wiedzę i podzielane przekonania (Jacobs, 2015, s. 41-42, 48-56).

W przypadku dedukcyjnego śledzenia procesu, niezbędne jest generowanie przewidywań (testów), które będą odróżniać działanie czynników materialnych i wpływ idei zawartych w umysłach aktorów biorących udział w procesie decyzyjnym. We wszystkich przypadkach ważne jest zebranie odpowiedniego materiału i wykorzystanie go do przetestowania lub zbudowania teorii ideowych w przekonujący sposób, odnoszący się do wyżej zarysowanych wskazówek (Jacobs, 2015, s. 56-63).

\section{Śledzenie praktyki}

Badacze i badaczki zainteresowani ideami często skłaniają się ku interpretatywistycznym ujęciom nauk społecznych. Biorąc pod uwagę ukierunkowanie śledzenia procesu na 
wyjaśnianie przyczynowe, można wątpić w możliwość jego pogodzenia z epistemologią interpretatywistyczną. W najnowszych publikacjach metodologicznych wyraźne staje się jednak stanowisko dopuszczające takie połączenie (zob. Bennett, Checkel, 2015a, s. 14-15; Checkel, 2015, s. 95). Wyrazem tej tendencji jest propozycja takiej modyfikacji metody, która oparta byłaby na interpretatywistycznym rozumieniu celów i granic możliwości przedsięwzięć naukowych (zob. Schwartz-Shea, Yanow, 2012) i skupiała się na praktykach (Pouliot, 2015) - stąd nazwa śledzenie praktyki (practice tracing).

Interpretatywizm odrzuca pozytywistyczne założenia, że nauka jest „dyskursem uprzywilejowanym poznawczo", oferującym coraz bliższe prawdy rozumienie świata (Wendt, 2008, s. 44; Schwartz-Shea, 2015). Z tego względu punktem wyjścia dla śledzenia praktyki jest uznanie, że dociekania w ramach nauk społecznych mogą ustalić przyczynowość jedynie lokalnie. To kontekst nadaje ludzkim praktykom ich społeczne znaczenie i moc wpływania na świat społeczny. Z drugiej jednak strony, żadne społeczne relacje nie są na tyle unikalne, by nie dało się ich ująć w pewne ogólniejsze, teoretyczne ramy, poprzez wyabstrahowanie wzorców znaczącego działania z lokalnego kontekstu i konceptualizowanie mechanizmów społecznych, które mogą być użyteczne w innych przypadkach (Pouliot, 2015, s. 237-238).

Practice tracing stawia zatem przed sobą dwa cele. Po pierwsze, wykazać lokalną przyczynowość, uchwycając powiązania generatywne (generative links) pomiędzy różnymi procesami społecznymi. Po drugie, wytworzyć analityczne, uogólnione wnioski, przydatne do spojrzenia wykraczającego poza konkretny przypadek (Pouliot, 2015, s. 239).

Praktyki to według Pouliota (2015, s. 241; por. Adler, Pouliot, 2011, s. 4) ,pposiadające społeczne znaczenie i zorganizowane wzorce działania” - innymi słowy „sposoby robienia czegoś". Ludzkie praktyki składają się z trzech warstw. Pierwszą z nich stanowi aspekt materialny, jest to pewne zachowanie jednostek ludzkich. Druga warstwa to znaczenie, jakie jest zachowaniu nadawane i które przekształca je w działanie. Wreszcie warstwa trzecia, a więc zorganizowanie we wzorcu, przeistacza działanie w praktykę.

Praktyki mają kluczowe znaczenie dla świata społecznego. Zarówno struktury jak i poszczególne podmioty sprawcze są ostatecznie efektem tego, co ludzie robią. To praktyki i związane z nimi interakcje tworzą i odtwarzają struktury świata społecznego (Wendt, 2008, s. 144-146, 289). Pierwszym krokiem do ustalenia lokalnej przyczynowości musi być zatem zbadanie praktyk. Praktyka nabiera znaczenia w danej sytuacji, to znaczy pewne działanie jest określoną praktyką w danym kontekście, a może być inną w innym (Pouliot, 2015, s. 243).

Kluczowe jest zrekonstruowanie „logiki praktyczności”, czyli zasobu intersubiektywnej i w większości milcząco przyjmowanej do wiadomości wiedzy o sposobie robienia pewnych rzeczy, która krystalizuje społeczne znaczenia określonego wzorca działania (Pouliot, 2015, s. 244; Wagner, 2008, s. 10; por. Adler-Nissen, 2016). Co więcej, w stosownych okolicznościach praktykowanie danej praktyki powoduje następne praktyki. W jednym i drugim wypadku moc przyczynowa praktyki zależy od znaczeń, które są z nią związane (Pouliot, 2015, s. 241-243).

Poszukujący przyczynowości muszą zatem dokonać interpretacji kontekstu społecznego - mówiąc obrazowo usiąść na płocie odgradzającym ,wspólnotę praktyki” od wspólnoty badawczej, aby móc wytworzyć wiedzę wierną temu, co dzieje się w pierwszej, a zarazem wartościową dla drugiej. Konieczne jest skupienie się na indukcyjnym 
odkrywaniu praktycznych znaczeń i lokalnie ustanowionego „zdrowego rozsądku”, bez wtłaczania ich w przyniesione przez osobę prowadzącą badania kategorie naukowe (Pouliot, 2015, s. 242-244).

Tak zidentyfikowane i umieszczone w kontekście praktyki można, w kolejnym kroku, wyabstrahować z ich kontekstu, by sformułować mechanizmy wykraczające poza dany przypadek. Według Pouliota $(2015$, s. 238-239, 251) nie są one jednak „bytami ontologicznymi", jak to postulują Bennett i Checkel, lecz wyłącznie teoretycznymi konstruktami analitycznymi, o abstrakcyjnym charakterze przynależnym „wirtualnej rzeczywistości" nauk społecznych. Poszukiwanie analitycznej ogólności (analytical generality) w tym ujęciu skupione jest na osiagnięciu takiego poziomu konceptualizacji, który umożliwia czynienie użytecznych porównań między przypadkami należącymi do danej klasy (Pouliot, 2015, s. 239).

W śledzeniu praktyki łączą się indukcja, interpretacja i abstrakcja, które należy postrzegać jako procesy wzajemnie się wzmacniające. Zadaniem tego procesu jest przede wszystkim ustalenie, dlaczego pewna praktyka (a nie jakaś inna) stoi za obiektem dociekań, a w drugiej kolejności, jak owa praktyka wpisuje się w różne kategorie teoretyczne (Pouliot, 2015, s. 239-240). Zarazem brakuje tu obecnego w śledzeniu procesu aspektu weryfikacji. Wiąże się to z ujęciem epistemologicznym, w którym można mówić o wiarygodności generalizacji jedynie na poziomie skontekstualizowanych praktyk, to znaczy zgodności ich ujmowania z materiałem empirycznym. Na poziomie mechanizmów, tak jak są tu rozumiane, analityczne ogólności nie mogą być prawdziwe ani fałszywe, bo są to, jak wspomniano, jedynie analityczne konstrukty nauk społecznych. Oceniać je należy według ich użyteczności w zrozumieniu nieuporządkowanego zbioru praktyk (Pouliot, 2015, s. 239, 251-252).

Ze względu na skupienie na tym, co ludzie robią i jakie znaczenie temu nadają, najwłaściwszym podejściem do zbierania danych na potrzeby śledzenia praktyki są techniki badań etnograficznych, zwłaszcza obserwacja uczestnicząca. Zazwyczaj jednak ten sposób zbierania materiału empirycznego nie jest wykonalny i konieczne jest poszukiwanie jego zamienników, najczęściej w postaci wywiadów i analizy tekstów (zob. Wiśniewska, 2013). Kluczowe znaczenie ma wychwycenie tego, co niedopowiedziane, niewyartykułowanych założeń, milczącej wiedzy o sposobie radzenia sobie w danej sytuacji - treści które należałoby dodać do tego, co faktycznie zostało powiedziane, by miało to sens (Soss, 2014). Rozmówczynie i rozmówcy w wywiadach czy też autorzy i autorki sprawozdań, gdy formułują i werbalizują myśli, np. odpowiadając na pytania, sami stają się po trosze teoretykami, przez co gubią część ,prawdy swojej praktyki”. Stąd też, mimo najlepszych starań i refleksyjności po stronie osoby prowadzącej badania, musi ona zdawać sobie sprawę, że zebrany przez nią materiał stanowi jedynie wstępnie zracjonalizowane przez samych aktorów odzwierciedlenie ich praktyk (Pouliot, 2015, s. 244-247).

\section{Podsumowanie}

Śledzenie procesu to rodzaj studium przypadku służącego formułowaniu lub weryfikowaniu opartych na mechanizmach wyjaśnień przyczynowych. Celem artykułu było zaprezentowanie metody śledzenia procesu. W części pierwszej omówiono istotę metody i jej cechy wyróżniające, zwłaszcza ujęcie przyczynowości oparte na mechanizmach. 
Druga część tekstu służyła przedstawieniu trzech wariantów śledzenia procesu: podobieństw i różnic między nimi, a także charakterystycznego dla każdego z nich sposobu prowadzenia analizy. Część trzecia wskazała na potencjał metody dla badań skupionych na czynnikach i teoriach ideowych. W ostatniej części tekstu poświęcono uwagę możliwości łączenia process tracing i ujęć interpretatywistycznych.

Pozorna intuicyjność śledzenia procesu sprawia, że łatwo o błędne wnioskowanie przy słabym wykorzystaniu metody sprowadzonej do rekonstrukcji zdarzeń lub pracy detektywistycznej (Bennett, Checkel, 2015a, s. 5, 22; przykłady dobrego zastosowania metody, por. Checkel, 2015). Istotne jest zwłaszcza precyzyjne ujmowanie mechanizmów przyczynowych w kategoriach teoretycznych i uwzględnianie wyjaśnień alternatywnych, co pozwala zwiększyć wiarygodność wniosków wyciąganych przez osobę prowadzącą badania (Checkel, 2015, s. 90; Beach, Pedersen, 2013, s. 98; Bennett, Checkel, 2015a, s. 23). Należy również brać pod uwagę potencjał leżący w komplementarności śledzenia procesu i innych metod (Schimmelfennig, 2015, s. 104; por. Dunning, 2015).

\section{Bibliografia}

Adler E., Pouliot V. (2011), International practices, „International Theory”, vol. 3 , nr 1.

Adler-Nissen R. (2016), Towards a Practice Turn in EU Studies: The Everyday of European Integration, „JCMS: Journal of Common Market Studies”, vol. 54, nr 1.

Bates R. H., Greif A., Levi M., Rosenthal J-L., Weingast B. R. (1998), Analytic Narratives, Princeton University Press, Princeton.

Beach D. (2013), Taking Mechanisms Seriously?, „European Political Science”, vol. 12, nr 1.

Beach D. (2017), Process-Tracing Methods in Social Science, http://politics.oxfordre.com/view/10.1093/ acrefore/9780190228637.001.0001/acrefore-9780190228637-e-176, 5.07.2017.

Beach D., Pedersen R. B. (2013), Process-Tracing Methods. Foundations and Guidelines, University of Michigan Press, Ann Arbor.

Bennett A., Checkel J. T. (2015a), Process tracing: from philosophical roots to best practices, w: Process Tracing. From Metaphor to Analytic Tool, red. A. Bennett, J. T. Checkel, Cambridge University Press, Cambridge.

Bennett A., Checkel J. T. (red.) (2015b), Process Tracing. From Metaphor to Analytic Tool, Cambridge University Press, Cambridge.

Berger P. L., Luckmann T. (2010), Społeczne tworzenie rzeczywistości, tłum. Józef Niżnik, Wydawnictwo Naukowe PWN, Warszawa.

Blyth M. (2002), The Great Transformations, Cambridge University Press, Cambridge.

Burnham P., Gilland L. K., Grant W., Layton-Henry Z. (2008), Research Methods in Politics, Palgrave, Basingstoke.

Checkel J. T. (2005), It's the Process Stupid! Process Tracing in the Study of European and International Politics, „Arena Working Papers”, nr 26.

Checkel J. T. (2015). Mechanisms, process, and the study of international institutions, w: Process Tracing. From Metaphor to Analytic Tool, red. A. Bennett, J. T. Checkel, Cambridge University Press, Cambridge.

Czaputowicz J., Ławniczak K. (2015), Ankieta Teaching, Research and International Policy, 2014 $w$ Polsce. Raport z badań, Wydział Dziennikarstwa i Nauk Politycznych Uniwersytetu Warszawskiego, Warszawa.

5 Więcej na temat praktycznych uwarunkowań dobrego śledzenia procesu: Ławniczak, 2013, s. 77-80. 
Czaputowicz J., Ławniczak K., Wojciuk A. (2015), Nauka o stosunkach międzynarodowych $i$ studia europejskie w Polsce, Wydawnictwo Naukowe Scholar, Warszawa.

Dunning T. (2015). Improving process tracing: the case of multi-method research, w: Process Tracing. From Metaphor to Analytic Tool, red. A. Bennett, J. T. Checkel, Cambridge University Press, Cambridge.

Evangelista M. (2015). Explaining the Cold War's end: process tracing all the way down?, w: Process Tracing. From Metaphor to Analytic Tool, red. A. Bennett, J. T. Checkel, Cambridge University Press, Cambridge.

Evera S. Van (1997), Guide to methods for students of political science, Cornell University Press, Ithaca.

Finnemore M., Sikkink K. (1998), International Norm Dynamics and Political Change, „International Organization", vol. 52, $\mathrm{nr} 4$.

George A. L., Bennett A. (2005), Case Studies and Theory Development in the Social Sciences, MIT Press, London.

Jacobs A. M. (2015). Process tracing the effects of ideas, w: Process Tracing. From Metaphor to Analytic Tool, red. A. Bennett, J. T. Checkel, Cambridge University Press, Cambridge.

Kittel B., Kuehn D. (2013), Introduction: Reassessing the Methodology of Process Tracing, „European Political Science", vol. 12, nr 1.

Kuehn D. (2013). Combining Game Theory Models and Process Tracing: Potential and Limits, „European Political Science", vol. 12, nr 1.

Ławniczak K. (2013), Process tracing. Śledzenie mechanizmów przyczynowych, w: Metody jakościowe i ilościowe w badaniu organizacji i działania Unii Europejskiej, red. K. Ławniczak, Wydział Dziennikarstwa i Nauk Politycznych Uniwersytetu Warszawskiego, Warszawa.

Ławniczak K. (2014), Dezintegracja, konsolidacja czy status quo? Kryzys modernizacji w Unii Europejskiej a poszukiwanie nowego paradygmatu integracji, „Przegląd Europejski, vol. 34, nr 4.

Ławniczak K. (2015), Socialisation and decision-making in the Council of the European Union, „Przegląd Europejski”, vol. 38, nr 4.

Ławniczak K. (2017), Społeczne zakorzenienie aktorów procesu podejmowania decyzji w Radzie Unii Europejskiej, Wydawnictwo Naukowe SCHOLAR, Warszawa.

Manners I., Whitman R. (2016), Another Theory is Possible: Dissident Voices in Theorising Europe, „JCMS: Journal of Common Market Studies”, vol. 54, nr 1.

Mayntz R. (2004), Mechanisms in the Analysis of Social Macro-Phenomena, „Philosophy of the Social Sciences", $\mathrm{nr} 2$.

Mazák J. (2017), Process tracing: zkoumání kauzality v prípadových studiích, „Sociológia”, vol. 49, nr 1.

Pouliot V. (2015), Practice tracing, w: Process Tracing. From Metaphor to Analytic Tool, red. A. Bennett, J. T. Checkel, Cambridge University Press, Cambridge.

Rohlfing I. (2013), Varieties of Process Tracing and Ways to Answer Why-Questions, „European Political Science", vol. 12, nr 1.

Ruback T. J. (2010), 'Let Me Tell the Story Straight On': Middlemarch, Process-Tracing Methods and the Politics of Narrative, „The British Journal of Politics and International Relations”, vol. 12, nr 4.

Schimmelfennig F. (2015), Efficient process tracing: analyzing the causal mechanisms of European integration, w: Process Tracing. From Metaphor to Analytic Tool, red. A. Bennett, J. T. Checkel, Cambridge University Press, Cambridge.

Schmidt V. A., Thatcher M. (2013), Theorizing ideational continuity: the resilience of neo-liberal ideas in Europe, w: Resilient Liberalism in Europe's Political Economy, red. V. A. Schmidt, M. Thatcher, Cambrdige University Press, Cambridge.

Schwartz-Shea P. (2015), Interpretive Social Science, w: The Encyclopedia of Political Thought, red. M. Gibbons, John Wiley \& Sons, Hoboken. 
Schwartz-Shea P., Yanow D. (2012), Interpretive Research Design. Concepts and Processes, Routledge, New York.

Smeets S., Vennix J. (2014), 'How to make the most of your time in the Chair': EU presidencies and the management of Council debates, „Journal of European Public Policy”, vol. 21, nr 10.

Smeets S. (2016), Consensus and Isolation in the EU Council of Ministers, „Journal of European Integration", vol. 38, nr 1.

Soss Joe (2014), Talking our way to meaningful explanations. A practice-centred view of interviewing for interpretive research, w: Interpretation and method. Empirical research methods and the interpretive turn, red. D. Yanow, P. Schwartz-Shea, Routledge, London-New York.

Szymański A. (2015), Nauki polityczne w Polsce i państwach , starej” UE, „e-Politikon”, nr 14.

Tilly C. (2001), Mechanisms in political processes, „Annual Review of Political Science”, 2001, nr 4.

Trondal J. (2001), Is there any social constructivist-institutionalist divide? Unpacking social mechanisms affecting representational roles among EU decision-makers, „Journal of European Public Policy", vol. 8, nr 1.

Wagner L. M. (2008), Problem-Solving and Bargaining in International Negotiations, Nijhoff, Leiden.

Waldner D. (2015), What makes process tracing good? Causal mechanisms, causal inference, and the completeness standard in comparative politics, w: Process Tracing. From Metaphor to Analytic Tool, red. A. Bennett, J. T. Checkel, Cambridge University Press, Cambridge.

Wendt A. (2008), Spoteczna teoria stosunków międzynarodowych, Wydawnictwo Naukowe Scholar, Warszawa.

Wiktorska-Święcka A., Klimowicz M., Michalewska-Pawlak M., Moroń D. (2017), Inwestycje społeczne jako nowy paradygmat polityk publicznych w Unii Europejskiej, Wydawnictwo Naukowe SCHOLAR, Warszawa.

Wiśniewska J. (2013), Wywiad jako technika gromadzenia danych w badaniach jakościowych, w: Metody jakościowe $i$ ilościowe $w$ badaniu organizacji $i$ działania Unii Europejskiej, red. K. Ławniczak, Wydział Dziennikarstwa i Nauk Politycznych Uniwersytetu Warszawskiego, Warszawa.

Zürn M., Checkel J. T. (2007), Getting socialized to build bridges: constructivism and rationalism, Europe and the nation-state, w: International Institutions and Socialization in Europe, red. J. T. Checkel, Cambridge University Press, Cambridge.

\section{The process-tracing method in political science. Variants and application}

\section{Summary}

Process-tracing is a method of within-case analysis, which can provide causal explanations of various social phenomena. Its focus on developing and testing causal theories attracts interest among qualitative researchers who do not want to limit their inquiries to exploratory or descriptive aims. At the same time, the case-centric variant of process-tracing, in which theories are used pragmatically as heuristic devices, provides a systematic but also creative way of researching singular events and processes. This paper attempts to show what process-tracing is and what it is not, what its variants are and how they should be used. It also probes the ontological and epistemological limits of the method, by showing how it can be used in idealist and interpretive research.

Key words: qualitative research; causal mechanism; methodology; case study; practice tracing 
